\title{
Enhancing Environmental Knowledge through the Teaching of Indigenous Knowledge in Malawian Science Education
}

\author{
Michael M. Kretzer \\ ORCID iD: https://orcid.org/0000-0002-8603-0141
}

\author{
Steven Engler
}

Russell H. Kaschula

ORCID iD: https://orcid.org/0000-0002-5481-6748

\section{Anna Bönisch}

\section{Abstract}

Language policy within the education system influences the outcome for pupils in Malawi. This applies particularly for Science Education. The increased usage of African Languages and Indigenous Knowledge (IK) can help to enable a meaningful teaching of environmental content using a constructivism approach. Despite the changes of the language policy in 1994 to a more open and multilingual approach, English dominates Science Education. The curricula in the Malawian education system are 'Westernized', dominated by English and include little IK. Nevertheless, teachers include in their language practice(s) African Languages during lessons. This research focused on the following question: What are teachers' perceptions and experiences about the incorporation of IK in the teaching of Science (Agriculture) as means to develop an environmental knowledge that can be adopted by pupils?

Research was done in the Northern Region. To obtain insights of teachers' views a qualitative approach was selected. Teachers participated in 
semi-structured interviews. Language-related challenges were seen as hampering teaching and learning, as well as the focus on theory rather than practical content such as creating school gardens. Furthermore, teachers wished for a more balanced relationship between 'Western' Science and IK in Science Education to teach environmental content.

Keywords: Malawi, Indigenous Knowledge (IK), Environmental content, Science Education, Agriculture, African Languages

\section{Introduction}

When researching Indigenous Knowledge (IK) ${ }^{1}$, one comes across the case of the Hoodia plant that has been used for millennia as an appetite suppressant by the San people in Southern Africa. While the San-Hoodia case has received much attention through various media: academic publications, newspaper articles and documentaries, it highlights aspects of global relevance. Firstly, the exploitation by different global pharmaceutical and commercial enterprises from the global North reflect unequal power and economic conditions. Secondly, the San-Hoodia case raises questions about intellectual property of Indigenous Knowledge (IK) or the problem of biopiracy (Amusan 2017; Wynberg \& Chennelle 2009²). Wynberg and Chennells (2009: 90) emphasize that what 'triggered the public's imagination' was the involvement of the San, which are the oldest human inhabitants in Africa. They remain scarce and marginalized communities in Southern Africa, together with their IK about the Hoodia plant as a hunger and thirst suppressant.

This example of an (economic) usage of IK of a specific plant for medicine highlights some important aspects of IK. Firstly, it is still relevant

${ }^{1}$ The authors solely use the term IK for the purpose of clarification. The authors are aware of its multidimensional body of meanings and its depiction as inferior and primitive (Kincheloe and Steinberg 2008: 136). In our view the notion of 'indigenous ways of knowing' as envisaged by Masuku van Damme and Neluvhalani (2004) describes the concept better and will be defined later in this article.

${ }^{2}$ For a holistic and detailed description and analysis of the San-Hoodia Case, Wynberg (2009) is recommended. 
today. Secondly, the relationship between IK and Western Science $^{3}$ needs clarification. Thirdly, the question about intellectual property remains pivotal. In this article we examine the impact IK can have on the teaching of Science in schools. The question for research is: What are teachers' perceptions and experiences about the incorporation of IK in the teaching of Science (Agriculture) as means to develop an environmental knowledge that can be adopted by pupils?

Human behaviour has been changing the climate through their economic activities, causing major challenges for themselves, their livelyhoods and the environment. The root of climate change i.e. global warming is attributed to human activities - e.g. using fossil fuels and through deforestation (Kappas 2016: 98). Future generations are facing the most adverse effects of climate change (Karpudewan, Roth \& Abdullah 2015: 32). Lack of knowledge and ignorance about the consequences of one's activities on global climate change are the most important factors leading to the destruction of environmental balance. Cetin and Nisanci (2010: 1831) state that by enhancing environmental knowledge in schools, ignorance and environmental balance can be resolved. Petegem and Blieck (2006: 633) also emphasize the importance of pupils' education '[...] to support sustainability and to understand the nature of environmental problems and solutions for the conservation of the remaining environment'. Environmental knowledge could further prevent local and global effects of practices like littering, as it is shown to be one of children's most serious environmental concerns.

Research further displayed that children suggest solving the littering problem as a way to protect the environment (Strong 1998: 355). The focus on local environmental issues in education promotes pupil's awareness towards these topics. Moreover, Engler and Kretzer (2014: 229) suggest that a strengthened connection between everyday life and education could raise awareness of relevance and benefits of education to communities. Similarly, Layrargues (2000: 169) argues in his Brazilian case-study that through prioritizing 'real' local problems within environmental education, educators can raise their pupil's attention towards challenges faced in their communities, while improving the quality of life. This extends to countries

${ }^{3}$ By using the term Western Sciences, the authors refer to Europe/ North America and the usage of the term is solely for the purpose of reader's access and clarification. 
such as Malawi, which would benefit from relevant knowledge and skills about agriculture (Kretzer, Engler, Gondwe \& Trost 2017: 242).

The Northern Region was selected due to various reasons. It is remote and agriculture, poverty and child-labour play a more dominant role compared to the other parts of Malawi. The distance to economic hubs such as the capital Lilongwe or the city Blantyre in the far South of Malawi are immense. The effects of such characteristics are highlighted in the Fourth Integrated Household Survey (IHS4) 2016-2017. The Northern literacy rate is $84.9 \%$, significantly higher compared to the Central (72.1\%) and Southern (70.9\%) Region (National Statistical Office 2017: 25). Research has shown that the question of IK within Science Education remains important. Education systems in the global South rely mostly on Western Science for their Education. The effects on the pupil's mind-set and the educational outcomes will be discussed in this article.

The following section explains the conceptual framework, followed by the methodology. The article then provides examples of Science Education in the Global South. Furthermore the general schooling conditions and the curricular framework are analysed, followed by an investigation of the implementation and daily interactions during Science Education at public schools. The article ends with a conclusion and recommendations.

\section{Incorporating IK in Science Education - Theoretical Aspects and Implementation in Different Contexts}

The term IK is frequently used in academia as well as in popular media, but there are different terminological definitions. Furthermore, there are many incorrect assumptions. An example is the assumption that IKs are stable and monolithic knowledge systems. As the African continent is a place for multiple ethnic and linguistic groups, it is quite obvious that a multiplicity of IK exists. These differences are prevalent not only between different ethnolinguistic groups, but also within these groups. One of the characteristics of IK is its orality. This leads to its fluid character, its heterogeneity and its boundedness to the holder of that knowledge (Zegeye \& Vambe 2006). Hence, the term IK is problematic, as it suggests that 'knowledge' exists as a boxed item awaiting usage. A dichotomy between Western and IK must be avoided as such a binary opposition is artificial and neo-colonial in its core. All knowledge is fluid and adapts to changes over time (Kincheloe 
\& Steinber 2008: 143). To highlight its embeddedness in its socio-cultural, historical and environmental setting the term 'indigenous knowing' is preferable. This term better reflects its embeddedness in people's practices. It cannot be treated in an isolated way from the culture of the community where it is rooted. The term 'indigenous knowing' dates back to O'Donoghue and Neluvhalani (2002).

The following is an example of IK and African worldviews. They are closely related to each other (Kajira 2015; Le Grange 2012; Cloete 2011). The example of Ubuntu (or uMunthu as it is named in Chichewa) reveals that IK cannot be seen as isolated from its African worldview or culture. All concepts rooted in IK are closely related and interlinked with culture. Traditional African communities were organised communally instead of the individualistic and capitalistic Western value system. In Europe the idea of holism ended with the Protestant reformation (Breidlid 2009: 141). Therefore, both worldviews are very much contradictory. Ubuntu is expressed in many African communities through various oral poems and proverbs. African worldviews such as Ubuntu/uMunthu are deeply rooted in lived dependencies between the various members. Kayira (2015: 110) offers us the following example from Chichewa: 'kali kokha nkanyama, tili awiri ntiwanthu (when one is on their own, they are as good as a wild animal; however, when they are two, they form a community). Some curricula include Ubuntu/uMunthu as a concept worthy of learning and teaching. In the South African curriculum for example Ubuntu is one of the ten values from the Department of Education (DoE) published in the 2001 'Manifesto on Values, Education and Democracy' (South African Government 2001). ChiShona in Zimbabwe expresses the concept ukama, which includes nature (Gelfand 1981: 90). Thus, a human being is related and embedded not only with other human beings, but rather with the entire cosmos. Le Grange (2012: 62) offers the following comprehensive definition of ukama:

In short, the concept of ukama embodies an inseparable oneness between past, present and future generations. But ukama also means humanity's relatedness to the natural (biophysical) world, which is advanced through totemic ancestorhood.

Such concepts about relatedness, embeddedness and wholeness of an individual with the community and nature offer potential for an environ- 
mental education. Concepts such as Ubuntu/uMunthu are deeply embedded in the socio-cultural life and world-view (Breidlid 2009: 141). However, the teaching through English as LoLT fundamentally contradicts any inclusion of IKS. Cloete (2011: 36) defines the biggest weakness of English as 'its contextual disengagement from Africa's natural environment, cultural histories and indigenous knowledge systems'. English, as a global language is dynamic and flexible, able to adjust to new developments, but it is not related to the African landscape. African languages possess a variety of words and descriptions for certain landscapes, animals and agricultural activities. Such knowledge is vanishing among younger generations as it is not being utilized. Furthermore, global climate change and local environmental risks increase the pressure on nature and its capacity.

These concepts are interconnected with the socio-cultural setting, thus it is compelling to use African Languages for teaching these concepts as part of IK. Teaching in African languages can help to overcome the current unsatisfactory situation in many education systems in Sub-Saharan Africa, including Malawi. Few scholars complete their secondary schooling. Alongside other obstacles the language policy remains at the core of it:

Most local languages are still under-utilised in education throughout the continent. The school remains a locus where the voices of the majority of the people are silenced, as African children continue to be taught and learn in European languages (Djite 2008: 86).

One misconception requires clarification regarding teaching IK: It is not about 'turning back the clock, a return to 'old' ways of living' (Le Grange 2012: 64), but rather to conceptualize concepts of IK and teach them critically and 'normally' without romanticizing former ways of life (Kincheloe \& Steinberg 2008: 141). The following paragraph illustrates an example of IK in Science Education in the global South.

Science teachers in Ghana use textbooks which are more culturally relevant for pupils. Examples within these textbooks include 'authentic Ghanaian problems' (Mueller \& Bentley 2009: 57) about gold or beer production, and about environmental issues related to paint production. As these topics include engagement with local communities, this helps pupils to learn about tacit and local IKs. Such place-based education (Smith 2007) can help in many ways. It connects the local community with their school and 
fosters reciprocal engagement. Furthermore the local perspective helps the pupil to understand Science Education and it offers an opportunity to acknowledge and connect IK and Western Science during the lessons (Anderson 2006).

\section{Methodology}

Research was conducted in the Northern Region of Malawi. In order to answer the research questions, a three-fold approach was used, encompassing a literature review, semi-structured interviews and ethnographic research. The literature review includes grey literature such as textbooks and policy documents. To obtain a deeper understanding of the daily challenges regarding the curricula, semi-structured interviews with 14 teachers in three districts in the Northern Region (Figure 1) were held.

All teachers gave their consent prior to the interview for the interviews to be recorded, transcribed, analysed and published (Clifford, Cope, Gillespie, French \& Valentine 2016: 10). A semi-structured interview guideline (Dörnyei 2007: 136) including ten different questions was applied during the interviews (see Appendix A). This research was also part of a larger project together with Mzuzu University in Malawi. The interviewguide was developed with their support. A pre-test (Oksenberg, Cannell \& Graham 1991) was done by Mzuzu University to help develop an understandable and clear interview guide.

All interviews were conducted by one of the authors at the work place of the interviewees. This ensured familiarity for the interviewees, as well as some comfort (Longhurst 2016: 150-177; Lamnek 2010: 354). Interviewer-related biases were existent and influenced the interview situation and probably also the answers to some extent (Garrett 2010: 45-46; Groves 1989: 398-404). This fact was also included in the interpretation of the results. Arrangements were developed to reduce these effects. On the one hand, the interviewer raised the specific topics more than once during the interview situation in order to obtain more authentic answers. On the other hand, the results of the interviews are not a stand-alone result of this research. Rather, a multi-modal approach was applied, which leads to the third method used in the context of this research, namely ethnographic observations.

The data from the interviews was accompanied by an ethnographic research at the investigated schools. This helped to obtain further context 
Enhancing Environmental Knowledge through the Teaching of IK information about the teaching of Agriculture in Malawi.

Figure 1. Research area in Malawi. Source: Kretzer, based on Malawi Spatial Data

Portal (MASDAP)

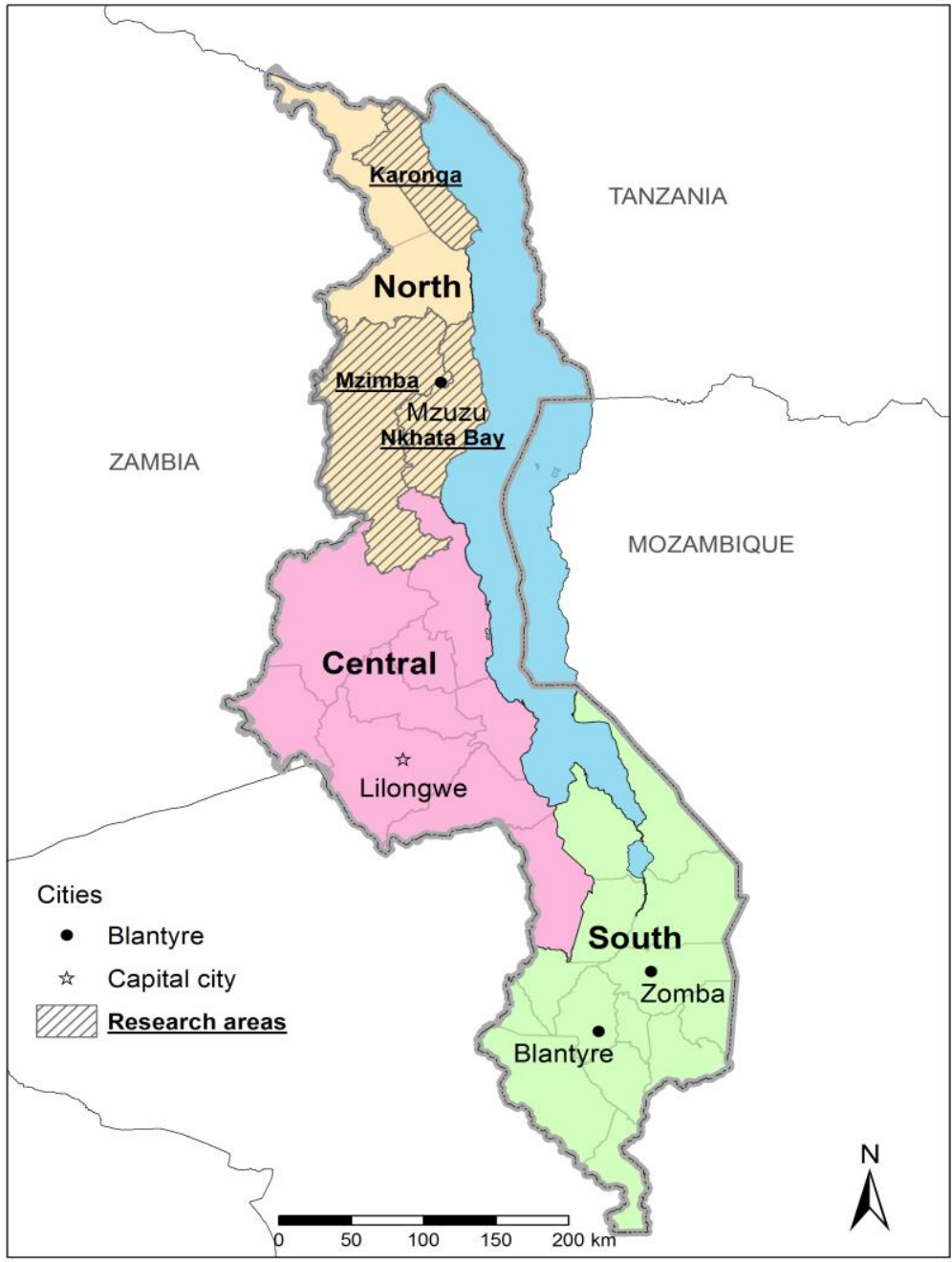




\section{Curricular Frame of IK and Environmental Teaching in Malawi}

As with all African colonies, formal and institutionalized education in Malawi started with the arrival of European missionaries in the $19^{\text {th }}$ century. Nevertheless, abundant forms of informal, indigenous ways of education existed prior to the European colonisation of then Nyasaland. It was only in 1926 that the British Colonial Administration established a Department of Education (Kretzer \& Kumwenda 2016: 25).

Post-independence, a 30-year dictatorship under Hastings Kamuzu Banda (1964 - 1994) followed. His education policy was contradictory. Firstly, he changed the name of the indigenous language Chinyanja ${ }^{4}$ to Chichewa (Kamwendo 2008: 354). Secondly, his education policy favoured English as Language of Learning and Teaching (LoLT) and provided Chichewa a marginalized position. Thirdly, he preferred classic languages such as Latin and Greek over the indigenous languages, in line with the approach of the elite Kamuzu Academy (Kamwendo 2010: 275).

After the first free multi-party elections in 1994 Bakili Muluzi became President until 2004. His Presidency focused on the so called 'zasintha' (things have changed) philosophy. He intended to use all indigenous Malawian languages equally (Green 2007: 61). This meant a change from linguistic assimilation under Banda to linguistic pluralism. He also implemented Free Primary Education (FPE) in accordance with the Jomtien World Conference on Education. This leads to a massive increase in enrolment rates, causing the teacher - pupil ratio to be negatively affected. At times teachers had up to 100 pupils in one classroom (DeStefano 2013). Additionally, the new Constitution of Malawi declared under Chapter IV, Section 25 a right to education for all its citizens (Constitution of Malawi 1998). President Muluzi also changed the language-in-education policy as part of his 'zasintha' philosophy. In March 1996 the Ministry of Education,

4 The literature is replete with different writing styles for the Malawian languages such as Chichewa as ChiChewa, chiChewa or Chewa. Differences have been noted for other languages too. In this article, the prefix Chi- is used for the languages as well as Chichewa as it is named in Malawi, whereas in Zambia or the official ISO 639-3 language code is nya as the language is named Chinyanja or Nyanja (SIl International 2017). 
Science and Technology (MoEST) published its directive No IN/2/14 in regard to language policy. This document declared indigenous languages as LoLT up to grade 4 (MoEST 1996).

The election of the late Bingu wa Mutharika in 2004 marked the implementation of further educational reforms. The 2007 new Curriculum and Assessment Framework (CASF) focussed on a more learner-centred approach and continuous forms of assessment during the lessons instead of a year-end examination (Chirwa and Naidoo 2014: 342; MoEST 2006). After his re-election in 2009 Mutharika defined education as being central to his political agenda. Nevertheless in this speech he only mentioned general educational challenges, but never referred to the indigenous languages or language policy in general (Mutharika 2009). The vast majority used English as LoLT and only a few schools used Chichewa or Chitumbuka, whereas other indigenous languages such as Chiyao, Chilomwe or Chisena were used in lower grades (Albaugh 2014: 260).

As with most African societies, political stakeholders and parents are quite resistant towards the usage of the First Language (L1) of the pupils and are clearly in favour of English (Brock-Utne 2000: 163 - 164). The idea of maximum exposure and its positive effect on the learning of English is very deeply rooted in parents' language attitudes (Brock-Utne 2005: 162). Furthermore, English is seen as the language offering upward social mobility (Kamwendo 2015: 34). Indigenous languages in Malawi lack this reputation and parents do not see any benefit in them (Matiki 2006: 246). Kamwendo (2010: 278) gives two examples about very negative language attitudes towards Chichewa at the university campus: ' $z a$ Chichewa zomwe zija mpaka kukhala nazo professor?' ('You mean that Chichewa has made him rise to full professorship?') or 'Inu kubwera ku university kudzaphunzira ndakatulo basi?' ('You came all the way to the university simply to study Chichewa poetry?'). Even though research showed the positive impact of usage of the L1, from the Malawi Institute of Education (MIE) (2010) and Langer (2010), nothing much has changed on the ground. Kanyumba, the previous education minister announced the new Language of Instruction (LoI) policy of the new Education Act 2012 in March 2014. In Section 78(1) the act stipulated that English shall be the LoLT from grade 1 onwards (Malawi Legal Information Institute 2012). Kamwendo (2016: 223) calls such policy 'a house standing on a shaky foundation'.

In addition to the new language policy, several other challenges ex- 
acerbate learning and teaching at public schools in Malawi. For example, studies from the Southern and Eastern Africa Consortium for Monitoring Educational Quality (SACMEQ) held in 2007 revealed that less than $25 \%$ of pupils in grade 6 had access to an individual mathematic textbook (SACMEQ III 2011). Other studies pointed out the extreme situation in subjects such as Science or Agriculture with up to 200 pupils using one textbook (DeStefano 2013). The Agriculture Curriculum named practical forms such as working with school gardens as an essential way to assess the pupils. Unfortunately the year-end examination paper from the Malawi National Examination Board (MANEB) did not include any question related to school gardens (MANEB 2015).

Earlier research from the Food and Agriculture Organisation (FAO) showed the competition between the school and community gardens, especially during a prolonged drought period (FAO 2007: 14). The quantity and quality of such school gardens varied in Malawi. Some schools do not have any school garden, while others have abandoned ones, while others are well maintained and integrated into the daily school activities.

Regarding Agriculture or Science Education in general, Shizha (2010) criticized the concentration on Western Science to the detriment of IK related content. This is true of most African curricula (Breidlid 2009: 141). Due to colonialism, and high dependency towards donor-aid agencies, this led Africans to develop an inferiority complex concerning IK. Hence, the majority of education systems in Sub-Saharan Africa 'continue to be grounded in Western viewpoints, marginalizing local indigenous ways of knowing' (Kayira 2015: 106). Many scholars such as Brock-Utne (2000: 157-162) or Mazrui (2004) blame the World Bank or other donor-aid agencies for favouring the previous colonial language. Languille (2016: 7396) analysed the involvement and relationships between British publishers, donor-aid agencies and government officials from United Kingdom and Tanzania. Within the new Primary Curriculum and Assessment Reform (PCAR) the Malawian government tried to overcome the above-mentioned challenges and biases. Nevertheless, studies showed that IK within the PCAR is limited to autochthonous technologies and not utilized as a holistic concept (Phiri 2008: 64). Furthermore, often only negative aspects of specific indigenous taboos are considered in the Malawian curriculum. This is alongside the negative attitude of pupils that perpetuates the subjugation of IK and indigenous languages compared to Western Science (Kayira 2015: 


\section{2; Glasson et al. 2010).}

There are scholars who advocate a radical position in relation to educational reform in Malawi and Africa. In the same way that gender studies are being infused in all areas of education, so too should environmental studies and Agriculture be emphasised holistically in Malawian education (Nampota 2011: 137). This offers the opportunity to include school gardens as a practical aspect regarding various kinds of environmental management. Agriculture and environmental education offer the opportunity for a constructivist way of teaching.

\section{Daily Implementation at Public Malawian Schools: Experiences from Teachers}

Many teachers mentioned the lack of equipment at their schools and the deteriorating teaching conditions, especially regarding Agriculture. As mentioned above, school gardens have a very high potential to enhance the teaching and learning of Agriculture at schools as it is not a purely theoretical subject, but rather allows the teachers to connect school activities with the daily life experiences of the pupils. This is a very pupil-centred approach and also a constructivist way of teaching (Reich 2012). Unfortunately, the researched schools did not all have a school garden. One of the researched schools had one, which was roughly around $500 \mathrm{~m}$ from the classroom buildings (see figure 2 below).

\section{Figure 2: School garden Source (Kretzer 2015)}

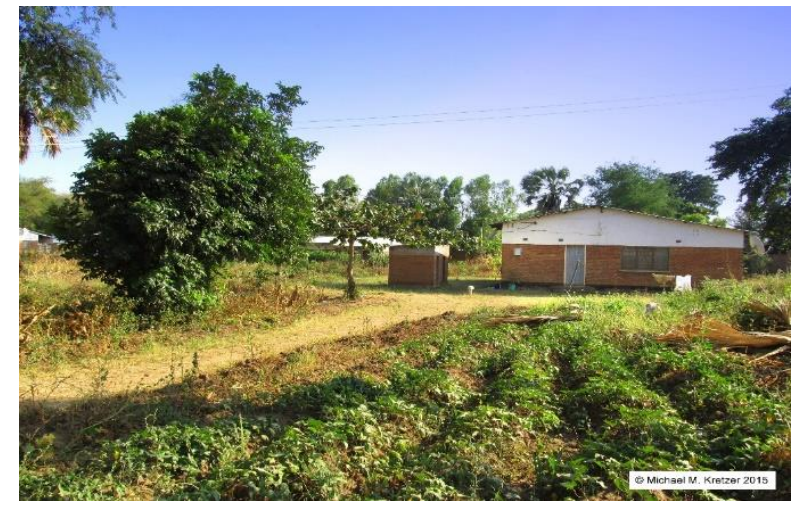


This impeded the inclusion of the school garden in the ordinary daily teaching routine. The school garden was in a mediocre condition. The demarcation of the school garden was unclear and there was no fence

Further, Teacher A, with 25 years' experience, and originally from Zimbabwe summed up the situation as follows:

Now there are problems in teaching the subject because mostly we are teaching agriculture ... theoretically, we are using a lot of theory other than practical because the skills can be transferred later if we apply or teach theory plus and then we go out into the gardens and then demonstrate how to do a particular practical, so that they should be able to acquire that skill practical as well and if that was the approach then that would help in ... excellent. But now there is a shortfall in that, there is a problem in that, practical is lacking, we are testing mostly theory and then even the practical which we conduct during examinations they are ... mostly theoretical, we don't go to the gardens, assess students in terms of what they are doing in the gardens. So ... that is weakening the subject a little bit ${ }^{5}$.

The few school books available for pupils focus on theory, but do occasionally include tasks related to a school garden (see figure 3).

\section{Figure 3: School book Source (Kretzer 2014)}

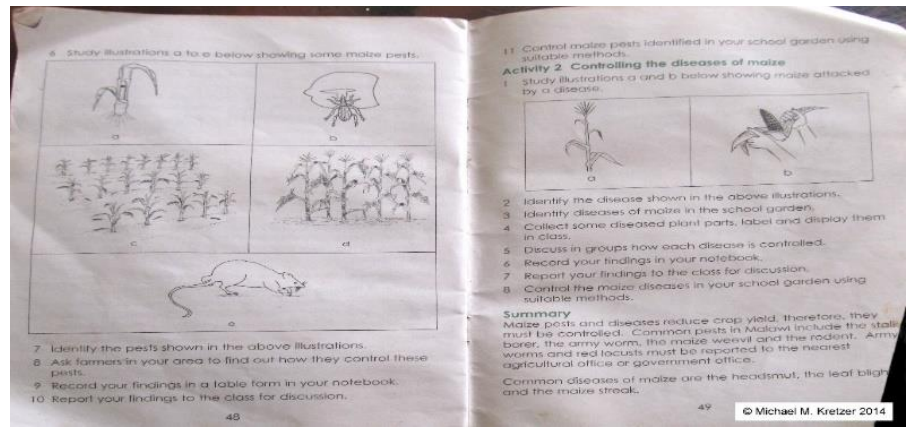

${ }^{5}$ All interviews were slightly edited regarding formulations or repeating of words to ensure a better reading of these interviews. 
The books assume the existence of gardens at Malawian schools, which is clearly not the case. On another note it is quite positive to see the inclusion and combination of theory and practice in school books. Some teachers who worked at several schools point out that at all these schools and the neighbouring schools they never saw any school garden.

Earlier studies in one district of the Northern Region described the effects of a connection between Agriculture as a subject, and the daily agricultural activities the pupils do at home. Pupils benefit from an integration of true-to-life content and theory. The usage of African languages in Agriculture can further contribute to improve the low literacy levels in Malawi and motivate pupils to engage in reading activities (Engler and Kretzer 2014: 229). Some teachers pinpoint the fact that indigenous techniques and knowledge are taught, but using English, which hinders the learning process in the classroom.

In many interviews, teachers focused on aspects of soil erosion as one of the major aims of the subject. They highlight the importance of forestry management to avoid soil erosion, which is an important topic in textbooks (Kretzer et al. 2017: 247). Some of the teachers allowed Code Switching (CS) or translanguaging between English and African languages, depending on the school setting. This is very common for schools in SubSaharan Africa, as research showed in Botswana (Kretzer 2017) and South Africa (Kretzer and Kaschula 2019; Kretzer 2016a).

We talk about degradation, we talk about what are the causes, cutting down trees in our country, where at the end of the day there is rain coming and that rain encourage land loss [...] So we talk about how we can conserve water and soil, so somehow there is the relationship between forestry, how we can keep our trees, care about our trees in order, so that the soil, we can still have some.

A female teacher (Teacher B), who had 20 years' experience, described the long-lasting influence of Agriculture on children. If Agriculture is taught in a pupil-centred way and includes use of African languages, the children can connect this knowledge with their informally acquired agricultural knowledge. Hence, the pupils can help their family members and community with sharing their classroom knowledge. This has potential for synergy effects (Kretzer 2016b: 256). 
Another female teacher (Teacher C) spoke very passionately about IK and its inclusion into the teaching of Agriculture. She spoke in a reflective way about seeds and plants. From her perspective, certain plants such as hybrid plants and seeds are preferable, but for others the local indigenous varieties should be used. Observations showed peoples' preferences for local varieties, such as rice. Furthermore, the textbook is in clear favour of the hybrid seeds, whereas her teaching is more balanced, considering the people's preferences and without Western bias. She states:

There are so many in fact crops, like sweet potatoes, so the Malawians they plant local varieties, but if we talk about maize, we encourage they must according to the book they talk about crop improvement, whereby we show them that, you know that in order to increase the, they must plant the hybrids, ... so in another way we still encourage like for maize that they should really buy those seeds from the shops, but for sweet potatoes, cassava they just use their home, the remaining ones, they take these stems and plant for another season, so this are one of the things they can do.

Nevertheless, many teachers concentrate on the difference between local (containing IK) and international plants. Some teachers state that they teach about traditional Malawian cattle species and about exotic livestock only in theory. For IK related aspects, they are closely connected to day-to-day real life experiences of the pupils (Mawere 2015: 63).

$\mathrm{Ja}$, indigenous knowledge is part of the subject, because most of the time when we are teaching them, they start from the local knowledge, that's when we go maybe exotic, for example we can talk about the types of vegetables, we group them into two. Indigenous vegetables as what and what and exotic vegetables, if we go to the cattle, we have indigenous and the exotic ones. [...] So we try to compare what are the advantages and disadvantages, and to see where we have the weaknesses or the strengths, how can we improve our indigenous varieties (Teacher C).

Another male teacher (teacher E) focused specifically on this constructivist approach. At the beginning of all his lessons he tried to connect 
the topic and new knowledge with some existing concepts from the pupils. Hence, he sees IK as a very important part for teaching Agriculture in a meaningful way and to instil some environmental competencies.

Yes, that knowledge indeed is incorporated in our lesson, because before we introduce the lesson we asked them what they do at their homes as far as maybe storage or processing of food crops ... so students will contribute what they know, that's indigenous knowledge, because that one is knowledge from where? From their parents, knowledge that has been passed down from one generation, yes it is incorporated and it is used [...] Students may not know why they carry such steps so it is up to us teachers to explain why certain steps are carried out.

Teacher F, a male teacher from the same school as teacher E explains that they work together as colleagues to support each other. It is very important for them, as all of them never studied Agriculture, but rather other subjects such as Geography, Mathematics or Biology, so they all teach outside of their subject area. This is a common problem for the subject Agriculture. He explained how he includes IK in his teaching and how he learns from other local practices, which he was not aware of. The following example relates to pest prevention for husbandry farmers. This example is important for many rural farmers, who cannot afford vaccination or medication for their livestock, using indigenous plants, which is also better for the environment.

We look at the diseases and how can they be prevented. Sometimes we do ask the students and some of their way diseases of chickens are prevented at their homes or how do they control them, most of the local farmers they don't have access to vaccination, but in the villages they do have their own way, their traditional ways of controlling diseases. I remember in one of the lessons a student told me that they do use aloe vera to control diseases or mainly to prevent diseases. [...] almost each and every day they do add aloe vera, they do extract the fluid from the leaves, then they add it, mix it with the water and give it to the chicken. [...] So we do include IK in teaching and sometimes we do get the information from the students. 


\section{Conclusion}

In this article we examined the question of how the incorporation of IK in the teaching of Agriculture through African languages can help to enhance environmental knowledge in the Northern region of Malawi. As shown, IK, worldviews and African languages are very closely related. Hence, teaching of Agriculture through English is artificial and hinders cognition. Teachers use CS to help pupils and they try to connect the existing local knowledge of pupils as a starting point of their lessons. The change of the language policy with the Education Act 2012, is counter-productive, and further research is required on the effect of this policy on teaching in Malawi. Nevertheless, negative language attitudes and negative attitudes towards agricultural activity by the younger generation must be considered as it hampers the future development of Malawi. There remains an underlying dichotomy and stratification between IK and Western concepts.

A constructivist approach helps to include IK and to enable meaningful learning. Many teachers use IK mainly for differences in plants and livestock selection, fewer for different agricultural techniques. Teachers spoke about usage of indigenous plants instead of medicine for livestock vaccination and the importance of forestry management. Furthermore, it was found that the lack of school gardens hinders teaching of Agriculture. School gardens offer the opportunity to combine theory and practice and illustrate both IK and Western concepts.

A curricular change is necessary to include more holistic IK concepts. Properly qualified teachers of Agriculture are also needed. If African societies, such as Malawi, do not value their own languages, heritage and knowledge, and they continue to define themselves as inferior in relation to Western concepts, development will remain difficult and environmental degradation will continue. A combination of IK and Western concepts for the subject Agriculture can ensure meaningful and sustainable teaching for Malawian pupils.

\section{Disclosure Statement}

No potential conflict of interest was reported by the authors. 
Enhancing Environmental Knowledge through the Teaching of IK

\section{References}

Albaugh, E.A. 2014. State-Building and Multilingual Education in Africa. New York: Cambridge University Press.

https://doi.org/10.1017/CBO9781107323735

Amusan, L. 2017. Politics of Biopiracy: An Adventure into Hoodia/ Xhoba Patenting in Southern Africa. African Journal of Traditional Complementary Alternative Medicine 14,1: 103 - 109.

https://doi.org/10.21010/ajtcam.v14i1.11;

PMid:28480387 PMCid:PMC5411860

Anderson, I. K. 2006. The Relevance of Science Education, as Seen by Pupils in Ghanaian Junior Secondary Schools. Cape Town: University of Cape Town.

Bas, M., G.T. Teksoz \& H. Ertepinar 2011. Emphasizing Local Features for Effective Environmental Education: Environmental Attitudes of Elementary School Students Living in Ancient Halicarnassus (Turkey). Science Education International 22,2: 119 - 132.

Breidlid, A. 2009. Culture, Indigenous Knowledge Systems and Sustainable Development: A Critical View of Education in an African Context. International Journal of Educational Development 29: 140 - 148. https://doi.org/10.1016/j.ijedudev.2008.09.009

Brock-Utne, B. 2005. But English is the Language of Science and Technology: On the Language of Instruction in Tanzania. In BrockUtne, B., Z. Desai \& M. Qorro (eds.): LOITASA Research in Progress. Dar es Salaam: KAD Associates.

Brock-Utne, B. 2000. Whose Education for All? The Recolonization of the African Mind. Studies in Education/ Politics. Volume 6. New York \& London: Falmer Press.

Cetin, G. \& S.H. Nisanci 2010. Enhancing Students' Environmental Awareness. Procedia-Social and Behavioral Sciences 2,2: 1830 - 1834. https://doi.org/10.1016/j.sbspro.2010.03.993

Chirwa, G. \& D. Naidoo 2014. Curriculum Change and Development in

Malawi: A Historical Overview. Mediterranean Journal of Social Sciences 5,16: $336-345$.

https://doi.org/10.5901/mjss.2014.v5n16p336

Clifford, N., M. Cope, T. Gillespie, S. French \& G. Valentine 2016. Getting Started in Geographical Research: How this Book can Help. In Clifford, 
Michael M. Kretzer et al.

N., M. Cope, T. Gillespie \& S. French (eds.): Key Methods in Geography. Los Angeles: SAGE Publications.

Cloete, E.L. 2011. Going to the Bush: Language and the Conserved Environment in Southern Africa. Environmental Education Research 17:1, 35-51. https://doi.org/10.1080/13504621003625248

DeStefano, J. 2013. Teacher Training and Deployment in Malawi. In Motoko, A. (ed.): Teacher Reforms around the World: Implementation and Outcomes 19: 77 - 97.

https://doi.org/10.1108/S1479-3679(2013)0000019009

Djite, P.G. 2008. The Sociolinguistics of Development in Africa. (Multilingual Matters 139.) Clevedon: Multilingual Matters.

Dörnyei, Z. 2007. Research Methods in Applied Linguistics. Oxford: Oxford University Press.

Engler, S. \& M.M. Kretzer 2014. Agriculture and Education: Agricultural Education as an Adaptation to Food Insecurity in Malawi. Universal Journal of Agricultural Research 2,6: 224 - 231.

Garrett, P. 2010. Attitudes to Language. Key Topics in Sociolinguistics. Cambridge: Cambridge University Press.

Gelfand, M. 1981. Ukama: Reflections on Shona and Western Cultures in Zimbabwe. Gwelo: Mambo Press.

Glasson, G.E., N. Mhango, A. Phiri \& M. Lanier 2010. Sustainability Science Education in Africa: Negotiating Indigenous Ways of Living with Nature in the Third Space. International Journal of Science Education 32,1: 125 - 141.

https://doi.org/10.1080/09500690902981269

Green, C. 2007. Discursive Strategies in Political Speech: The Words of Dr. Bingu wa Mutharika. Journal - Issues in Political Discourse Analysis 2,1: $59-74$.

Groves, R.M. 1989. Survey Errors and Survey Costs. Hoboken, New Jersey: John Wiley and Sons. https://doi.org/10.1002/0471725277

Kamwendo, G.H. 2016. The New Language of Instruction Policy in Malawi: A House Standing on a Shaky Foundation. International Review of Education 62: 221 - 228. https://doi.org/10.1007/s11159-016-9557-6

Kamwendo, G.H. 2015. The Straight for English Policy in Malawi: The Road not to be Taken. In Miti, L.M. (eds.): The Language of Instruction Question in Malawi. Cape Town: The Centre of Advanced Studies of African Society. (CASAS Book series 113.) 
Kamwendo, G.H. 2010. Denigrating the Local, Glorifying the Foreign:

Malawian Language Policies in the Era of African Renaissance. International Journal of African Renaissance Studies - Multi-, Interand Transdisciplinarity 5,2: $270-282$.

https://doi.org/10.1080/18186874.2010.534850

Kamwendo, G.H. 2008. The Bumpy Road to Mother Tongue Instruction in

Malawi. Journal of Multilingual and Multicultural Development 29:5, 353 - 362. https://doi.org/10.2167/jmmd547.0

Kappas, M. 2016. Klimawandel und Gesundheit. In Tamcke, M. (ed.): Armut und Gesundheit. Göttingen: Göttingen International Health Network (GIHN) and Institut für Ökumenische Theologie, Georg-AugustUniversität, Göttingen.

Karpudewan, M., W.M. Roth \& M.N.S.B. Abdullah 2015. Enhancing

Primary School Students' Knowledge about Global Warming and Environmental Attitude Using Climate Change Activities. International Journal of Science Education 37,1: 31 - 54.

https://doi.org/10.1080/09500693.2014.958600

Kayira, J. 2015. (Re)creating Spaces for uMunthu: Postcolonial Theory and Environmental Education in Southern Africa. Environmental Education Research 21,1: 106 - 128.

https://doi.org/10.1080/13504622.2013.860428

Kincheloe, J.L. \& S.R. Steinberg 2008. Indigenous Knowledges in Education: Complexities, Dangers, and Profound Benefits. In Denzin, N.K., Y.S. Lincoln, L.T. Smith (eds.): Handbook of Critical and Indigenous Methodologies. Thousand Oaks, London: SAGE Publications.

https://doi.org/10.4135/9781483385686.n7

Kretzer, M.M. 2017. Linguistic Repertoire and Language Practices of Pupils at Secondary Schools in Botswana: A Case Study. In Ralarala, M., K. Barris, E. Ivala \& S. Siyepu (eds.): African Language and Language Practice Research in the $21^{\text {st }}$ Century: Interdisciplinary Themes and Perspectives. Cape Town: Centre for Advanced Studies of African Society (CASAS BOOK SERIES.)

Kretzer, M.M. 2016a. Variations of Overt and Covert Language Practices of Educators in the North West Province: Case Study of the Use of Setswana and Sesotho at Primary and Secondary Schools. South African Journal of African Languages 36,1: 15 - 24. 
Michael M. Kretzer et al.

https://doi.org/10.1080/02572117.2016.1186891

Kretzer, M.M. 2016b. Chancen und Grenzen von 'Agriculture' als Schulfach

für eine nachhaltige Lebensführung. Fallstudie Karonga, Nkahata Bay und Mzimba Distrikt in Malawi. In Engler, S., W. Bommert \& O.

Stengel (eds.): Regional, Innovativ und Gesund - Nachhaltige

Ernährung als Teil der großen Transformation. Göttingen.

Vandenhoeck \& Ruprecht.

Kretzer, M.M. \& R.H. Kaschula 2019. (Latent) Potentials to Incorporate and

Improve Environmental Knowledge Using African Languages in

Agriculture Lessons in Malawi. In Leal, W. \& S. Hemstock (eds.):

Climate Change and the Role of Education. Climate Change

Management, published by Springer.

Kretzer, M.M., S. Engler, J. Gondwe \& E. Trost 2017. Fighting Resource

Scarcity - Sustainability in the Education System of Malawi: Case

Study of Karonga, Mzimba and Nkhata Bay district. South African

Geographical Journal 99: 3: 235 - 251.

https://doi.org/10.1080/03736245.2016.1231624

Kumwenda, J. \& M.M. Kretzer 2016. Language Policy in Malawi: A Study of its Contexts, Factors for its Development and Consequences. Marang: Journal of Language and Literature 27: 20 - 38.

Lamnek, S. 2010. Qualitative Sozialforschung. Weinheim und Basel: Beltz Verlag.

Langer, A. 2010. Unterrichtssprache und kognitive Entwicklung:

Fallstudien aus Malawi. Münster: LIT Verlag.

Languille, S. 2016. The Scramble for Textbooks in Tanzania. African Affairs

115,458: 73 - 96, https://doi.org/10.1093/afraf/adv060

Layrargues, P.P. 2000. Solving Local Environmental Problems in

Environmental Education: A Brazilian Case Study. Environmental

Education Research 6,2: 167 - 178. https://doi.org/10.1080/713664670

Le Grange, L. 2012. Ubuntu, Ukama and the Healing of Nature, Self and

Society. Educational Philosophy and Theory 44,sup 2: 56 - 67.

https://doi.org/10.1111/j.1469-5812.2011.00795.x

Longhurst, R. 2016. Semi-structured Interviews and Focus Groups. In

Clifford, N., M. Cope, T. Gillespie \& S. French (eds.): Key Methods in

Geography. Los Angeles: SAGE Publications.

Malawi Institute of Education (MIE) 2010. Learning Achievements of Standards 3 and 7 Learners in Malawi. Domasi: Government Printer. 
Malawi Legal Information Institute 2018. Education Act, 2012 (Accessed on 9 November 2018.)

https://malawilii.org/mw/legislation/act/2012/35

Malawi National Examination Board (MANEB) 2015. Malawi School Certificate of Education Examination, Agriculture. Zomba.

Malawi Spatial Data Portal 2015. Malawi Administrative Boundaries (GAUL). Available at: http://www.masdap.mw/maps/197 (Accessed on 10 April 2015.)

Masuku van Damme, L.S. \& E.F. Neluvhalani 2004. Indigenous Knowledge in Environmental Education Processes: Perspectives on a Growing Research Arena. Environmental Education Research 10,3: 353 - 370. https://doi.org/10.1080/1350462042000258189

Matiki, A.J. 2006. Literacy, Ethnolinguistic Diversity and Transitional Bilingual Education in Malawi. International Journal of Bilingual Education and Bilingualism 9,2: 239 - 254.

https://doi.org/10.1080/13670050608668643

Mawere, M. 2015. Indigenous Knowledge and Public Education in SubSaharan Africa. Africa Spectrum 50:2, 57-73.

https://doi.org/10.1177/000203971505000203

Mazrui, A. 2004. English in Africa: After the Cold War. (Multilingual Matters 126.) Clevedon: Multilingual Matters.

https://doi.org/10.21832/9781853596919

Ministry of Education Science and Technology (MoEST) 2006. Malawi Primary Education Curriculum and Assessment Framework (CASF) Draft. Lilongwe: Ministry of Education.

Ministry of Education Science and Technology (MoEST) 1996. Use of Mother Tongue as Medium of Instruction in Standard 1, 2, 3 and 4: A Circular from the Secretary for Education, Science and Technology to Education Institutions. (Ref. No. IN/2/4 dated 28 March, 1996.) Lilongwe: Ministry of Education.

Mueller, M.P. \& M.L. Bentley 2009. Environmental and Science Education in Developing Nations: A Ghanaian Approach to Renewing and Revitalizing the Local Community and Ecosystems. The Journal of Environmental Education 40,4: 53 - 64. https://doi.org/10.3200/JOEE.40.4.53-64

Mutharika, B. wa 2015. The Work of my Hands Speaks for Me. Inaugural Speech 2009. Available at: 
Michael M. Kretzer et al.

http://unpan1.un.org/intradoc/groups/public/documents/cpsi/unpan036

183.pdf (Accessed on 17 January 2015.)

National Statistical Office 2018. Fourth Integrated Household Survey (IHS4)

2016 - 2017. Available at:

http://www.nsomalawi.mw/images/stories/data on line/economics/ihs /IHS4/IHS4\%20REPORT.pdf (Accessed on 16 November 2018.)

Nampota, D. 2011. Exploring the Potential and Challenges of Integrating Environmental Issues in Formal Education in Malawi. African Journal of Research in Mathematics, Science and Technology Education 15:3, 137 - 152. https://doi.org/10.1080/10288457.2011.10740723

Oksenberg, L., C. Cannell \& G. Kalton 1991. New Strategies for Pretesting Survey Questions. Journal of Official Statistics 7,3: 349 - 365.

Phiri, A.D.K. 2008. Exploring the Integration of Indigenous Science in the Primary School Science Curriculum in Malawi. PhD thesis, Virginia Polytechnic Institute and State University.

Reich, K. 2012. Das Lehr- und Studienbuch mit Online Methodenpool. Weinheim und Basel: Beltz Verlag.

SACMEQ - Southern and Eastern Africa Consortium for Monitoring Educational Quality (2011) 2014. SACMEQ III Main Report (2011). Available at:

www.sacmeq.org/sites/default/files/sacmeq/reports/sacmeq-

iii/national-reports/mal_sacmeq_iii_report-_final.pdf

(Accessed on 22 February 2014.)

Shizha, E. 2010. The Interface of Neoliberal Globalization, Science Education and Indigenous African Knowledges in Africa. Journal of Alternative Perspectives in the Social Sciences 2: 27 - 58.

SIL International 2018. 639 Identifier Documentation: nya. (Accessed on 16 November 2018.) https://iso639-3.sil.org/code/nya

Smith, G.A. 2007. Place-based Education: Breaking through the Constraining Regularities of Public School. Environmental Education

Research 13,2: 189 - 207. https://doi.org/10.1080/13504620701285180 South African Government 2018. Manifesto on Values, Education and Democracy. Available at:

https://www.gov.za/sites/default/files/manifesto 0.pdf (Accessed on 16 November 2018.)

Strong, C. 1998. The Impact of Environmental Education on Children's Knowledge and Awareness of Environmental Concerns. Marketing 
Intelligence \& Planning 16,6: 349 - 355.

https://doi.org/10.1108/02634509810237523

Van Petegem, P. \& A. Blieck 2006. The Environmental Worldview of

Children: A Cross-cultural Perspective. Environmental Education Research 12,5: 625 - 635.

https://doi.org/10.1080/13504620601053662

Wynberg, R. \& R. Chennells 2009. Green Diamonds of the South: An Overview of the San-Hoodia Case. In Wynberg, R. et al. (eds.): Indigenous Peoples, Consent and Benefit Sharing: Lessons from the San-Hoodia Case. Dordrecht: Springer Science+Business Media B.V. https://doi.org/10.1007/978-90-481-3123-5_6

Zegeye, A. \& M. Vambe 2006. African Indigenous Knowledge Systems. Review 29,4: 329 - 358.

\section{Appendix 1: Interview Guide Malawi 2015}

\section{Interview Guide Malawi 2015}

\section{Person:}

Institution:

Day/Time:

Place:

\section{Questions:}

1. What is the role of the subject Agriculture/Natural Science within PCAR?

2. What are the main aims of the subject Agriculture in Malawi? 
3. How is the general situation / equipment (regarding human resources, materials and other aspects) of your school regarding teaching in general and teaching Agriculture in specific?

4. What kind of areas and aspects of the concept of sustainability are part of Agriculture and/ or the general curriculum?

5. What ideas or concepts are taught regarding the usage of water or energy within Agriculture or common school days? Is the concept of sustainability taught/used?

6. Are school gardens common in Malawi? How are they used within Agriculture lessons? (Are pupils responsible for these gardens including watering, cultivation and harvesting?)

7. Is indigenous knowledge part of the subject Agriculture or within the general science curriculum?

8. How much funding/support do you receive from the government? Is it adequate for agricultural activities? Does the school raise funds through extra-cultural activities?

9. Do you have the infrastructure that is used in agricultural activities?

10. How much time is set aside for both agricultural practical's and theory?

Dr Michael M. Kretzer

Research Associate Ruhr-University Bochum Department of Geography Bochum, Germany and

Honorary appointment School of Languages \& Literature African Language Section Grahamstown/ Makhanda, South Africa Michael.Kretzer@ruhr-uni-bochum.de 
Enhancing Environmental Knowledge through the Teaching of IK

Dr Steven Engler

Research Associate

Ruhr-University Bochum

Department of Geography

Bochum, Germany

Prof Dr Russell H. Kaschula

Senior Professor

African Language Studies Department

University of the Western Cape

Bellville

Cape Town

rrkaschula@uwc.ac.za

Anna Bönisch

Research Associate

Ruhr-University Bochum

Department of Geography

Bochum, Germany 